\title{
Estimation of evacuation time with elevator application in high-rise buildings
}

\author{
Marina Gravit ${ }^{1}$, Ivan Dmitriev ${ }^{1, *}$, and Kirill Kuzenkov ${ }^{1}$ \\ ${ }^{1}$ Peter the Great St. Petersburg Polytechnic University, Polytechnicheskaya 29, St. Petersburg, \\ 195251, Russia
}

\begin{abstract}
The article considers elevator application as an integral part of the main evacuation path from high-rise multi-storey buildings and structures. The evacuation ways are rather long in this building type. It makes the evacuation process difficult and dangerous, and sometimes physically impossible. The combined evacuation with using of vertical transport can solve this problem. The complex of buildings of various storeys $(20,30 \ldots 60)$ was modeled in the program complex Pathfinder. We determine and compare the values of the evacuation time for different health categories people during movement on stairs and with particular elevator use. The percentage of acceleration of evacuation is given. It is shown that evacuation along the staircase develops as a linear function. The necessary of the joint stair-lift evacuation method increases with the height of the building. We offer the human flow ratios for evacuating people in simulated buildings $(20,30 \ldots 60)$, which is made taking into account the various mobility categories.
\end{abstract}

\section{Introduction}

Regulatory documents categorically forbid the use the elevators for evacuation during the fire for a long time in the Russian Federation. In [1] an exception was made for a low-mobility population group M4 category (according to [2]) and allowed to use the special fire lifts to save them. Staircases are the only evacuate way from building for all other people. Despite the fact that special fire safety requirements are imposed on high-rise buildings [3-8], people evacuation in emergency case is not sufficiently reliable in this way. Evacuation on the stairs takes quite a long time because of the low people movement speed as well as the local narrowing places at the entrances and exits to the staircase. Especially it is worth noting that the stairs are not able to provide sufficient capacity to organize the people evacuation from the high-rise building [9]. Evacuation paths usually exceed 100 meters, so it causes fatigue, absent-mindedness and carelessness, which can lead to injuries. This evacuation way becomes especially difficult, dangerous, and at times physically impossible for elderly people and people with reduced mobility [10].

The vertical transport design includes the elevators number selection by their speed and load-lifting characteristics. This process is regulated by the interstate standard ISO 4190-1:

\footnotetext{
* Corresponding author: i.i.dmitriev@yandex.ru
} 
2010 Passenger elevators, which describes the main parameters and sizes of this technical equipment. Elevators are usually grouped into a single staircase-elevator block. Shuttle elevators are used in a multi-storey building to provide vertical links between the various types of sections [11].

The article [12] emphasizes the necessity of special transit zones inside the building. It divides a single high-altitude structure into a complex of isolated fireproof compartments [13-15]. These intermediate technical floors in addition to the main purpose (the location of the building's networks and communications) are converted into recreation and safety areas for people during evacuation. The number of floors within one section should not exceed 1820 floors [16]. The project provides safety zones every 20 floors. Volume-planning solutions should be determined by taking into account the requirements of fire safety [17] and the fire influence of on the structure [18-21] which without additional fire protection are vulnerable [22-26].

Most problems with the elevator use as one of the main evacuation path have been resolved. The fire safety requirements for elevator designs are as high as for staircases. The article compares the fire safety of stairs and elevator and justifies their similarity [27].

The article presents the "idealized" time of people's movement during evacuation. It can be realise with the most result convergence only during training alarms, when all people are in a calm state and do not fear for their lives. Most people are proned to panic in fire case, what adversely affects on the behaviour adequacy in a critical situation [28]. The local narrow places is passed calmly, quietly waiting for their turn in the simulation model. In fact, it is a great possibility of human falling and a temporary passage blockage. Also, the falling and injury risks are not considered when driving on the stairs. A tragic example of this situation is the six-hour evacuation from the World Trade Centre in New York in 1993 [29]. Therefore, the actual evacuation time along the ladder will usually exceeds the theoretical time from the program model calculations [30]. The vertical transport system is maximally protected from the human factor, which allows us to consider that evacuation time with using elevators is close to reality.

The purpose of this article is to investigate the possibility of using elevators as one of the main path from high-rise buildings and structures.

To achieve this goal, the following tasks have been accomplished:

- the people evacuation time of different health categories in simulated multi-storey office buildings of different heights $(20,30 \ldots 60$ floors $)$ has been determined;

- the comparison of the time of evacuation on a staircase and through elevators;

- the human flow selection settings was made to reach the extremum of the estimated evacuation time.

\section{Materials and Methods}

The theoretical base of the methods for calculating the elevator movement, including evacuation, are presented in the studies [31,32]. We use the modelling method in this article and simulate high-rise multi-storey building in the Pathfinder PC [33-35]. The evacuation time was calculated using both ladders exclusively and with partial use of vertical elevator units. The calculations were carried out taking into account the presence of an immobile population group. A unit of calculation time (time step), which is responsible for the simulation results validity, is taken equal 0.25 seconds. This correction refines the study results, which were obtained earlier at 0.5 seconds [36].

The following parameters of the calculated building were adopted:

100 people per floor ( 1 person per $6 \mathrm{~m}^{2}$ usable area $\left(600 \mathrm{~m}^{2}\right)$ ). The people ratio in the mobility groups M1, M2, M3, M4 is taken equal 90, 4, 4, 2. An excessive number of lowmobility was accepted because of the demographic trend; 
Two U-shaped stairs of type H3, a march of $1350 \mathrm{~mm}$;

The elevator inside the section is designed for 13 people;

The lift-shuttle is designed for 26 people. These are vertical connections of the 1 st floor of the building and the 1 st floor of the next section;

Each 20th floor is a technical (fireproof zone);

Evacuation start time $=2.8$ minutes (170 seconds). [37].

Fig. 1. Floor plan of the modelled building.

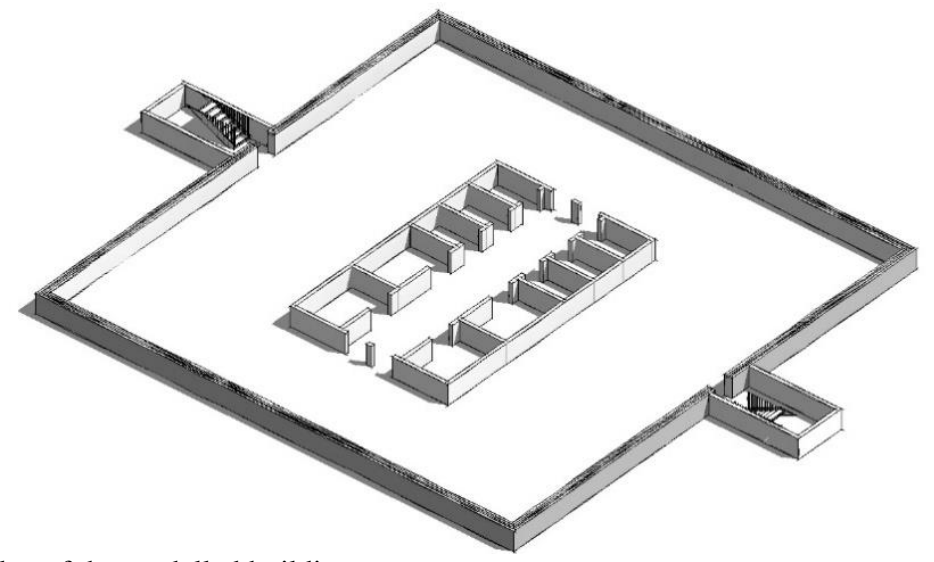

Table 1 provides information on the number of elevators and shuttle-lifts for the buildings.

Table 1. The number of elevators and shuttle-lifts in buildings.

\begin{tabular}{|c|c|c|c|c|c|}
\hline Floors & 20 & 30 & 40 & 50 & 60 \\
\hline Elevators & 6 & 8 & $6 \cdot 2=12$ & $6+8=14$ & $6 \cdot 3=18$ \\
\hline Shuttle-lifts & 0 & 0 & 2 & $2 \cdot 2=4$ & $2 \cdot 2=4$ \\
\hline Number of agents (people) & 1900 & 2900 & 3800 & 4800 & 5700 \\
\hline
\end{tabular}

\section{Results and Discussion}

We calculate the evacuation time for buildings in 20,30 ... 60 floors using exclusively stairs, and with partial evacuation through vertical transport. The results are summarized in Table 2.

Table 2. Estimated evacuation time for simulated buildings.

\begin{tabular}{|c|c|c|c|c|c|c|}
\hline Floor & $\begin{array}{c}\text { Evacuation } \\
\text { time on the } \\
\text { stairs, sec }\end{array}$ & $\begin{array}{c}\text { Difference } \\
\text { between } \\
\text { floors, sec }\end{array}$ & $\begin{array}{c}\text { Evacuation } \\
\text { time with } \\
\text { using } \\
\text { elevators, sec }\end{array}$ & $\begin{array}{c}\text { Difference } \\
\text { between } \\
\text { floors, sec }\end{array}$ & $\begin{array}{c}\text { Difference between } \\
\text { evacuation on the } \\
\text { stairs and with } \\
\text { elevators, sec }\end{array}$ & $\begin{array}{c}\text { Percentage of } \\
\text { acceleration } \\
\text { of evacuation, } \\
\text { sec }\end{array}$ \\
\hline 20 & 850 & - & 720 & - & 130 & $15.3 \%$ \\
\hline 30 & 1202 & 352 & 868 & 148 & 334 & $27.8 \%$ \\
\hline 40 & 1520 & 318 & 1071 & 203 & 449 & $29.5 \%$ \\
\hline 50 & 1873 & 353 & 1220 & 149 & 653 & $34 . \%$ \\
\hline 60 & 2190 & 317 & 1490 & 270 & 700 & $32.0 \%$ \\
\hline
\end{tabular}




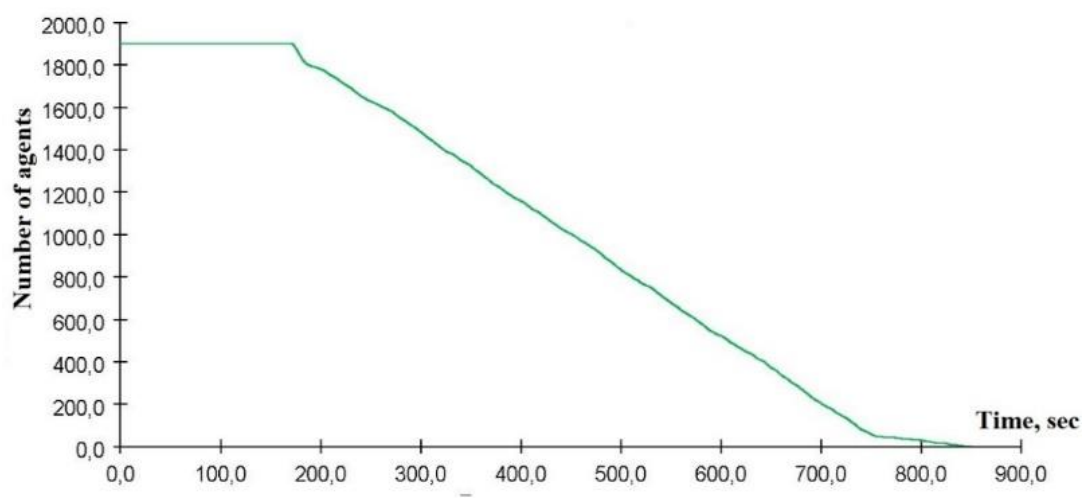

Fig. 2. The dependence graph of the evacuated people from 20 -storey building along the stairs.

The evacuation time obtained is confirmed by the theoretical results presented in [38] for one ladder and partially shown in Table 3 . It should be borne in mind that Table 3 shows the lower limit of the time interval. Since there are two ladders in our building, the minimum evacuation time is reduced by 2 times.

Table 3. Minimum time for evacuation of a high-rise office building.

\begin{tabular}{|c|c|c|c|c|c|c|c|c|}
\hline \multirow{2}{*}{$\begin{array}{c}\text { March width, mm } \\
\text { project / effective }\end{array}$} & \multicolumn{8}{|c|}{$\begin{array}{c}\text { The minimum evacuation time of a high-rise office } \\
\text { building with the number of evacuating people through 1 } \\
\text { staircase, sec }\end{array}$} \\
\cline { 2 - 9 } & 500 & 1000 & 2000 & 3000 & 4000 & 5000 & 6000 & 7000 \\
\hline $1372 / 1176$ & 420 & 780 & 1500 & 2160 & 2880 & 3600 & 4320 & 5040 \\
\hline 2 stairs 1350 & 210 & 390 & 750 & 1080 & 1440 & 1800 & 2160 & 2520 \\
\hline
\end{tabular}

The trend (Fig.3) illustrate that evacuation time graph in both cases follows to a linear law with increasing the building height. The time trend in combined with the elevators variant is more gentle than solely on the stairs. Also, the percentage acceleration of evacuation is developing with the growth of the number of people.

It is worth mentioning separately that the evacuation time spent on overcoming the path along the stairs of ten floors is close to a constant value of 330 seconds (5.5 minutes). This is offset by the linearity of the human flow graph. However, this approach does not take into account the likely people slowdown, especially elderly and limited mobility, due to the problems of overcoming long distances at a fast pace. 


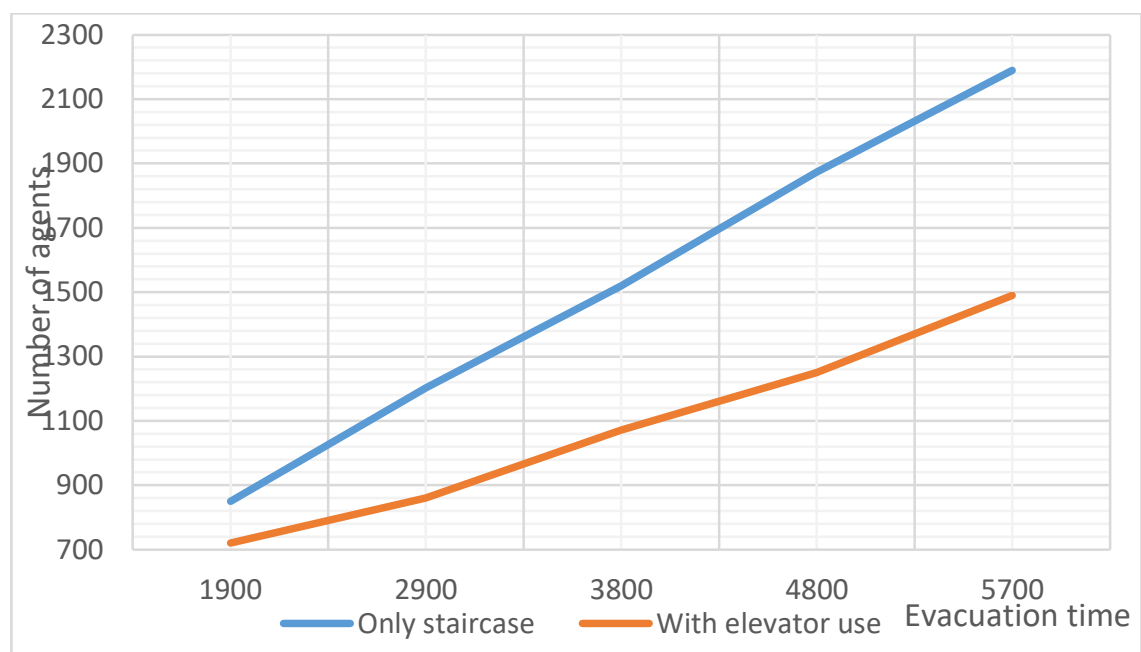

Fig. 3. Dependence of evacuation time on the number of agents (people).

For modelled buildings, the selection of the ratio of evacuating people relative to mobility categories is made (Table 4).

This selection was carried out on the basis of a dependence graph analysis of the evacuated people number from the time (Fig. 4). Without this setting, evacuation through staircases and elevators ends at different times. The point of simultaneous finish is the extremum (minimum) of the evacuation time function.

Table 4. Selection of the evacuated people ratios for simulated buildings.

\begin{tabular}{|c|c|c|c|c|}
\hline Building & Use elevators, category & $\%$ & Floor & Time, sec \\
\hline \multirow{2}{*}{20} & $\mathrm{M} 2-\mathrm{M} 3$ & $100 \%$ & $7-19$ & \multirow{2}{*}{720} \\
\hline & M1 & $30 \%$ & $10-19$ & \\
\hline \multirow{6}{*}{30} & Section 1 (1-19 floor) & & & \multirow{6}{*}{868} \\
\hline & $\mathrm{M} 2-\mathrm{M} 3$ & $100 \%$ & $7-19$ & \\
\hline & M1 & $40 \%$ & $10-19$ & \\
\hline & \multicolumn{3}{|l|}{ Section 2 (21-30 floor) } & \\
\hline & $\mathrm{M} 2-\mathrm{M} 3$ & $30 \%$ & $25-30$ & \\
\hline & M1 & $100 \%$ & $25-30$ & \\
\hline \multirow{6}{*}{40} & \multicolumn{3}{|l|}{ Section 1 (1-19 floor) } & \multirow{6}{*}{1071} \\
\hline & $\mathrm{M} 2-\mathrm{M} 3$ & $100 \%$ & $7-19$ & \\
\hline & M1 & $55 \%$ & $10-19$ & \\
\hline & \multicolumn{3}{|l|}{ Section 2 (21-39 floor) } & \\
\hline & $\mathrm{M} 2-\mathrm{M} 3$ & $100 \%$ & $21-39$ & \\
\hline & M1 & $\begin{array}{l}20 \% \\
40 \%\end{array}$ & $\begin{array}{l}25-30 \\
31-39\end{array}$ & \\
\hline \multirow{6}{*}{50} & Section 1 (1-19 floor) & & & \multirow{6}{*}{1220} \\
\hline & $\mathrm{M} 2-\mathrm{M} 3$ & $100 \%$ & $7-19$ & \\
\hline & M1 & $80 \%$ & $10-19$ & \\
\hline & \multicolumn{3}{|l|}{ Section 2 (21-39 floor) } & \\
\hline & $\mathrm{M} 2-\mathrm{M} 3$ & $100 \%$ & $21-39$ & \\
\hline & M1 & $\begin{array}{l}40 \% \\
40 \%\end{array}$ & $\begin{array}{l}25-30 \\
31-39\end{array}$ & \\
\hline
\end{tabular}




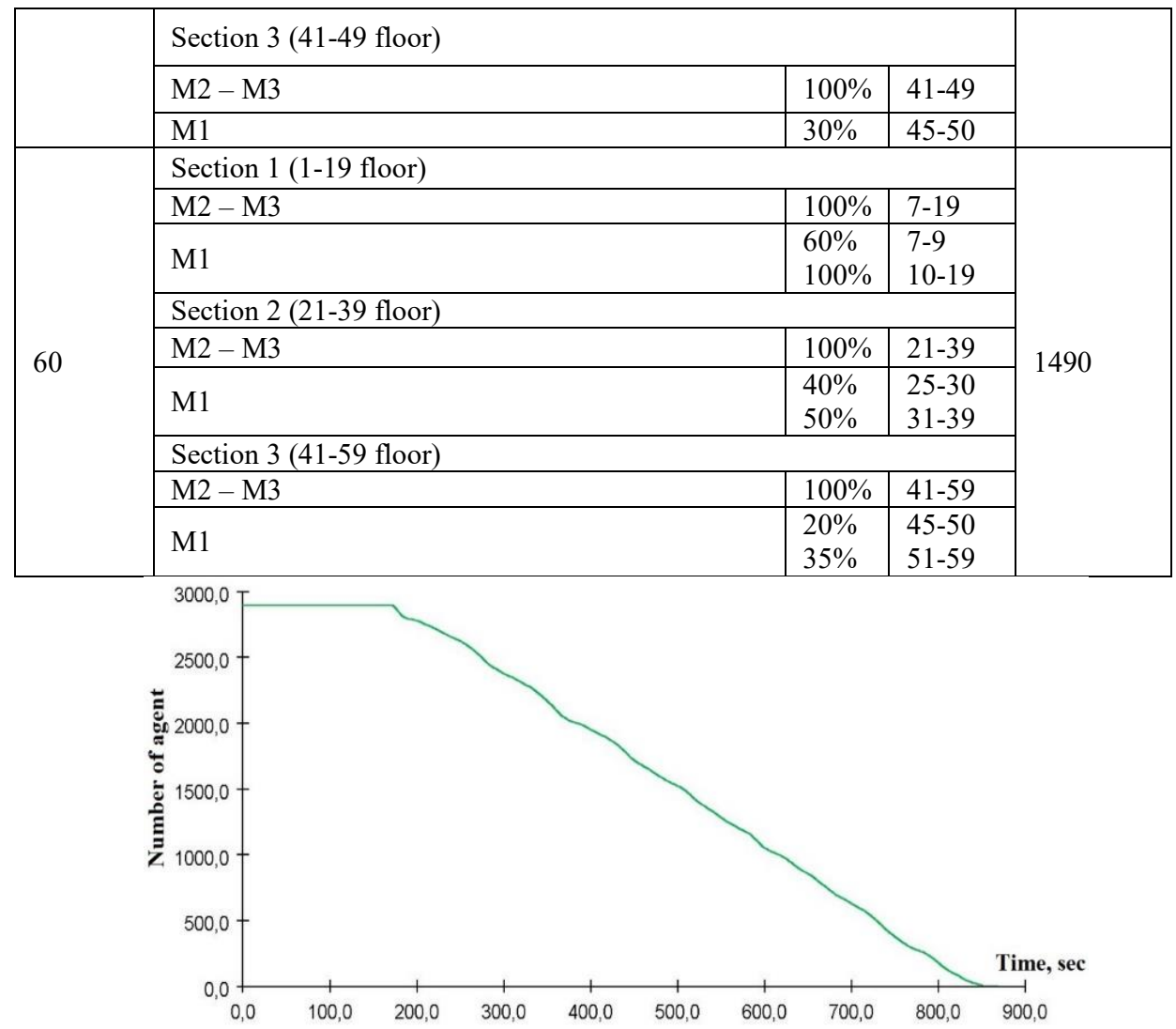

Fig. 4. Evacuated people dependence from time for a 30-storey building with using elevators.

\section{Conclusions}

The requirements for elevator fire safety are as high as for non-smoke-free staircases. Most prohibiting problems for elevator using as the main evacuation path have been resolved. World design experience confirms the efficiency of the complex evacuation.

The estimated evacuation time on stairs and through vertical transport for $20,30 \ldots 60$ storey buildings was obtained in the article. It is shown that evacuation along the staircase increases as linear function (which in general does not correspond to reality due to the fatigue factor and possible accidents). The graph (Fig. 3) shows that staircase-lift line is more gentle, which indicates the high efficiency of this method for high-rise buildings.

For simulated buildings $(20,30 \ldots 60)$, the most optimal selection of the human flow ratios of evacuating people is made, taking into account the various categories of mobility.

\section{References}

1. Federal Law 123. Technical regulations on fire safety requirements (as amended on July 29, 2017)

2. Set of rules 59.13330.2016 Accessibility of buildings and structures for persons with reduced mobility 
3. M. Lazarevska, M. Cvetkovska, M. Knezevic, A. Trombeva Gavriloska, M. Milanovic, V. Murgul, N. Vatin, Appl. Mech. Mater., 627 (2014)

4. M. Gravit, I. Dmitriev, A. Ishkov, IOP Conf. Ser. Earth and Env. Sc., 90, 012226 (2017)

5. T.A Hezhev, A.V. Zhurtov, A.S. Tsipinov, S.V. Klyuev, Mag. Civ. Eng., 80, 4 (2018)

6. M. Al Ali, S.A. Isaev, N.I. Vatin, Mat. Phys. Mech., 26, 1 (2016)

7. V.D. Zakhmatov, M.V. Silnikov, M.V. Chernyshov, J. Ind. Poll. Cont., 32, 2 (2016)

8. M.V. Sil'nikov, M.V. Chernyshov, L.G. Gvozdeva, Tech. Phys., 61, 11 (2016)

9. R.M. Patton, ASHRAE J., 15, 14 (1973)

10. V.V. Kholshchevnikov, D.A. Samoshin, Fire Exp. Saf., 15, 5 (2006)

11. L. Al-Sharif, E. Alosta, N. Abualhomos, Y. Suhweil, Build. Serv. Eng. Res. Tech., 38, 2, (2017)

12. A. Cowlard, A. Bittern, C. Abecassis-Empis, J. Torero, Proc. Eng., 62, 169 (2013)

13. M.V. Gravit, O.V. Nedryshkin, O.T. Ogidan, Mag. Civ. Eng., 77, 1 (2018)

14. O. Zybina, M. Gravit, Y. Stein, IOP Conf. Ser. Earth and Env. Sc., 90, 012227 (2017)

15. M.V. Gravit, E.V. Golub, S.P. Antonov, Mag. Civ. Eng., 79, 3 (2018)

16. L. Al-Sharif, Lift Report, 43, 5 (2017)

17. N.V. Gusakova, K.E. Filyushina, A.M. Gusakov, N.N. Minaev, Mag. Civ. Eng., 75, 7 (2017)

18. A.V. Alekseytsev, N.S. Kurchenko, Mag. Civ. Eng., 73, 5 (2017)

19. I.A. Korotchenko, E.N. Ivanov, S.S. Manovitsky, V.A. Borisova, K.V. Semenov, Yu.G. Barabanshchikov, Mag. Civ. Eng., 69, 1 (2017)

20. A.V. Bushmanova, N.V. Videnkov, K.V. Semenov, Yu.G. Barabanshchikov, A.V. Dernakova, V.K. Korovina, Mag. Civ. Eng., 71, 3 (2017)

21. V.A. Rybakov, I.A. Ananeva, A.O. Rodicheva, O.T. Ogidan, Mag. Civ. Eng., 74, 6 (2017)

22. T. Saknite, D. Serdjuks, V. Goremikins, L. Pakrastins, N. Vatin, Mag. Civ. Eng., 64, 4 (2016)

23. M.R. Garifullin, A.V. Barabash, E.A. Naumova, O.V. Zhuvak, T. Jokinen, M. Heinisuo, Mag. Civ. Eng., 63, 3 (2016)

24. I.N. Priadko, V.P. Mushchanov, H. Bartolo, N.I. Vatin, I.N. Rudnieva, Mag. Civ. Eng., 65, 5 (2016)

25. P.V. Bulat, M.V. Silnikov, M.V. Chernyshev, Res. J. Appl. Sc. Eng. Tech., 9, 6 (2015)

26. P.V. Bulat, M.V. Chernyshev, Int. J. Env. Sc. Educ., 11, 11 (2016).

27. V.V. Kholshchevnikov, Fire safety, 27, 1 (2018) 
28. K.O. Fryanova, V.A. Perminov, Mag. Civ. Eng., 75, 7 (2017)

29. M. Isner, T. Klem, Fire Invest. Rep. Nat. Fire Prot. Ass. (1994)

30. O.V. Nedryshkin, M.V. Gravit, Fire Safety, 2 (2018)

31. L. Al-Sharif, A. M. Abu Alqumsan, O. F. Abdel Aal, Build. Serv. Eng. Res. Tech., 34, 3 (2013)

32. L. Al-Sharif, A. M. Abu Alqumsan, Build. Serv. Eng. Res. Tech., 36, 3 (2015)

33. I. N. Karkin, S. V. Subachev, A. A. Subacheva, Fire Safety, 11 (2015)

34. M. Kadlic, V. Mózer, Proc. Eng., 192 (2017)

35. J.-J. Li, H.-Y. Zhu, Proc. Eng., 211 (2018)

36. I. Dmitriev, K. Kuzenkov, V. Kankhva, MATEC Web Conf., 193, $03030(2018)$

37. T.G. Merkushkina, D.A. Samoshin, Z.S. Khasueva, M.Yu. Zykova, Tech. Technosph. Sec., 5, 63 (2015)

38. J. Pauls, ASME Work. Focus Elev. Emer. High-Rise Build (New York, 2003) 